\title{
Adult-onset foveomacular vitelliform dystrophy
}

INSERM

\section{Source}

INSERM. (1999). Orphanet: an online rare disease and orphan drug data base. Adultonset foveomacular vitelliform dystrophy. ORPHA:99000

Adult-onset foveomacular vitelliform dystrophy (AOFVD) is a genetic macular dystrophy characterized by blurred vision, metamorphopsia and mild visual impairment secondary to a slightly elevated, yellow, egg yolk-like lesion located in the foveal or parafoveal region. 